\title{
Seasonal Variation of Calving in Murrah Buffalo in Bihar
}

\author{
V.V. Potdar ${ }^{*}$, J.R. Khadse, S.A. Joshi, Y.S. Gaundare, N.L. Phadke, M. Swaminathan and \\ A.B. Pande
}

Genetics Department, Central Research Station BAIF Uruli Kanchan, India

\begin{abstract}
The present study was carried out to estimate the seasonal variation of calving in Murrah buffaloes. The study was conducted in North West alluvial plain of Bihar (Chappra, Siwan and Samastipur), of India on 773 Murrah buffaloes, and these buffaloes were inseminated during June 2010 to December 2014 at BAIF's field Artificial Insemination centres which provide door-step artificial insemination service at village's level. The result indicated that the calving of Murrah buffaloes occurred throughout the year. In Chhapra maximum calving observed in August, i.e. $17 \%$ while $14 \%$ in October. September and November $13 \%$ each. Based on season majority of calving observed between July to January. In Samastipur maximum calving observed in August 16\% while in September $14 \%$ followed by November $13 \%$ and October month $11 \%$. Based on season majority of calving observed between July to January months. In Samastipur maximum calving observed in August $16 \%$ while in September $14 \%$ followed by November $13 \%$ and October $11 \%$. Based on season majority of calving found between July to January months. It could be concluded that Murrah buffaloes tend to calve more in the days with shorter photoperiod as compared to days with more extended photoperiod.
\end{abstract}

Keywords: Buffalo, Caving, agro-climatic zones.

\section{INTRODUCTION}

The Murrah breed is the essential genetic material of milk producing buffalo in India breed has been used extensively used throughout India to upgrade the nondescript buffalo stock to improve the milk production. Buffalo is tending seasonal pattern of breeding in India, while cattle show perennial breeding and calving pattern. The breeding pattern of buffaloes characterized by significant seasonal variation. This variation in breeding efficiency of buffaloes termed as seasonality of buffalo breeding. This seasonal variation in reproduction ultimately affects the reproductive traits like age at first calving, dry period and calving interval and hence the economics of milk production. Generally, the peak of calving observed during the winter season. Most of the animals are bred during colder parts of the year, thereby giving births to newborn mostly during winter only. Various workers have observed that very few buffaloes come in heat during a hotter period of a year. This condition is due to high environmental temperature, humidity or both during summer or rainy months. Minimal information is available on the seasonal trend in the calving of the buffaloes from Bihar state, so the objective of the study was to document the calving pattern of Murrah buffaloes in the Bihar.

\section{METHODOLOGY}

The study was planned to see calving pattern in Murrah buffaloes in Chappra, Siwan and Samastipur

*Address correspondence to this author at the Genetics Department, Central Research Station BAIF Uruli Kanchan, India; Tel: +91-20-26926248;

Fax: +91-20-26926347; E-mail: vinod.potdar@baif.org.in districts of Bihar. Total of 773. Murrah buffaloes considered for this study, and BAIF artificial insemination centres inseminated these buffaloes from June 2010 to December 2014. Data collected in a handheld device.

\section{RESULT}

The results of the present study indicated that the rainy and the autumn seasons were the main calving seasons for buffaloes when more than $70 \%$ of the calving took place. The result showed that the calving of Murrah buffaloes occurred throughout the year. In North West alluvial plain of Bihar maximum calving observed in August month $15.71 \%$ \& November $14.01 \%$. The findings of the present study were following the results of Hassan et al. (2007) and Hussain (2007) [1, 2] in Nili Ravi buffaloes in Pakistan. Anonymous (2008) [3] also reported the main calving period between July to December in Murrah, Pandharpuri, Jaffrabadi and Surti buffaloes Haryana, Maharashtra, Gujrat and Rajasthan states, respectively. District and month wise number of calving has shown in Table 1 below.

In Chhapra maximum calving observed in August, i.e. $17 \%$ while in October it was $14 \%$. September and November showed similar results, i.e.,13\%. But on the bases of season majority of calving found between July to January. In Siwan, maximum calving observed during November, i.e., $16 \%$ while $14 \%$ in August, which is followed by $13 \%$ both in September and October. Based on season majority of calving found between July to December months. In Samastipur maximum calving observed in August (16\%), September (14\%) 
Table 1: District Wise and Month Wise Number of Calving Observed

\begin{tabular}{|c|c|c|c|c|}
\hline Area & Chhapra & Siwan & Samastipur & Grand Total \\
\hline January & 19 & 7 & 16 & 42 \\
\hline March & 7 & 17 & 5 & 29 \\
\hline April & 10 & 0 & 2 & 12 \\
\hline June & 22 & 18 & 18 & 58 \\
\hline July & 32 & 28 & 18 & 78 \\
\hline August & 61 & 33 & 31 & 125 \\
\hline September & 47 & 31 & 26 & 104 \\
\hline Grand Total & 350 & 231 & 192 & 773 \\
\hline
\end{tabular}

\section{MONTH WISE CALVING PATTERN OF MURRAH BUFFALO IN SIWAN}

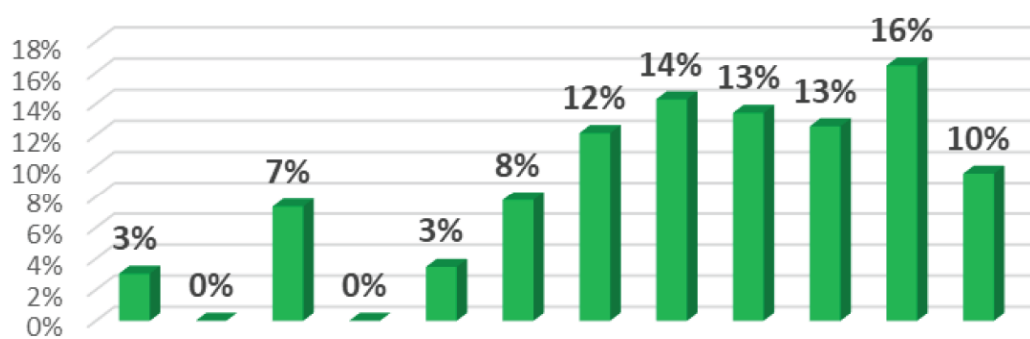

\section{MONTH WISE CALVING PATTERN OF MURRAH BUFFALO IN SAMASTIPUR}
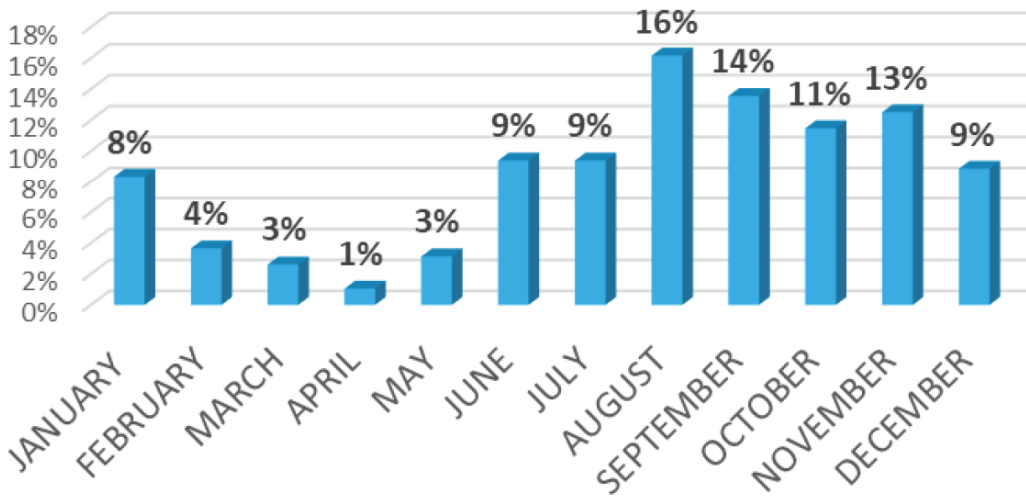


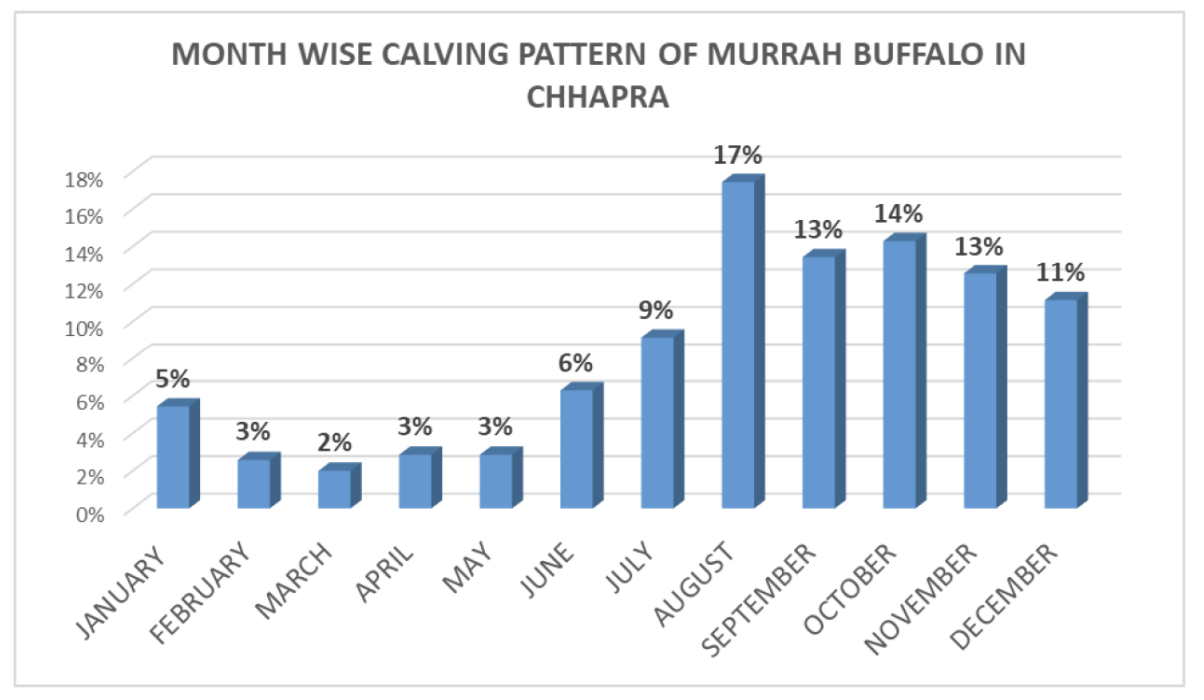

Table 2: District Wise and Season Wise Number of Calving Observed

\begin{tabular}{|c|c|c|c|c|c|c|}
\hline Area & AUTOMAN & RAINY & SPRING & SUMMAR & WINTER & Grand Total \\
\hline \hline Chhapra & 94 & 140 & 26 & 32 & 58 & 350 \\
\hline Siwan & 67 & 92 & 17 & 26 & 29 & 231 \\
\hline Samastipur - Vaishali & 46 & 75 & 14 & 24 & 33 & 192 \\
\hline Grand Total & 207 & 307 & 57 & 82 & 120 & 773 \\
\hline
\end{tabular}

followed by November (13\%) while in October $11 \%$. Based on season majority of calving observed between July to January months. These findings are similar with results of Potdar et al. (2019) [4] who reported the highest percentage of calving (36\%) took place during the rainy season (July to September), which followed by the autumn (29\%) and the winter seasons (17\%). The lowest percentage $(8 \%)$ of calving was recorded in the spring season while (9)\% calving observed in the summer season. Reddy et al. (1999) [5] also reported August to November the most favourable period for reproduction in Murrah buffaloes.

In Chhapra district when the data grouped according to the various seasons, the highest percentage of calving (40\%) took place in the rainy (July to September) season, which followed by the autumn $(27 \%)$ and the winter seasons $(17 \%)$. The lowest percentage $(7 \%)$ of calving recorded during the spring and $(9 \%)$ in the summer season. In Siwan when the data grouped according to the various seasons, the highest percentage of calving $(40 \%)$ took place in the rainy (July to September) season, which followed by the autumn (29\%) and the winter seasons (13\%). The lowest percentage $(7 \%)$ of calving recorded in the spring and (11\%) in the summer season. In Samastipur when the data grouped according to the various seasons, the highest percentage of calving $(39 \%)$ took place in the rainy (July to September) season, which followed by the autumn (24\%) and the winter seasons $(17 \%)$. The lowest percentage $(7 \%)$ of calving recorded in the spring and (13\%) in the summer season. The finding of the present study is in agreement with Anonymous 2 and Reddy et al. 15 in Murrah buffaloes in India. District and season wise number of calving has shown in Table 2 above.

Misra and Sengupta (1965) [6] reported that in India, the buffalo's sexual vigour declines during the summer and improves with the onset of the colder season. El-Sheikh (1987) [7] reported more than 63\% calvings occurred during the colder season in Egyptian buffaloes.

\section{CONCLUSION}

The results of the present study showed that season had been a prominent factor governing the calving pattern in Murrah buffaloes. Based on season majority of calving observed between July to January months. It can be concluded that Murrah buffaloes tend to calve more during the days with shorter photoperiod as compared to days with more extended photoperiod. 


\section{SEASON WISE CALVING PATTERN OF MURRAH BUFFALO IN CHHAPRA}

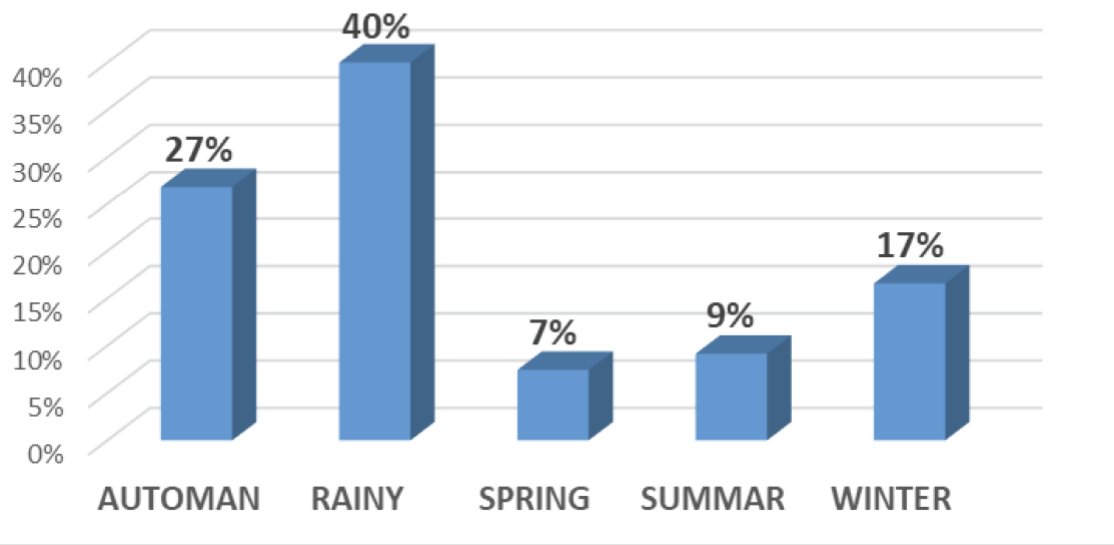

SEASON WISE CALVING PATTERN OF MURRAH BUFFALO IN SIWAN

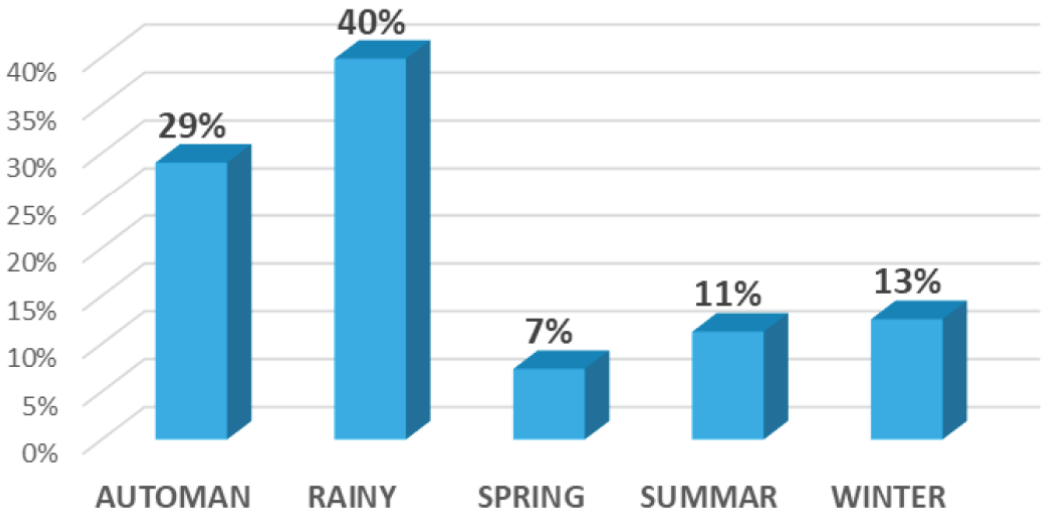

\section{SEASON WISE CALVING PATTERN OF MURRAH BUFFALO IN SAMASTIPUR}

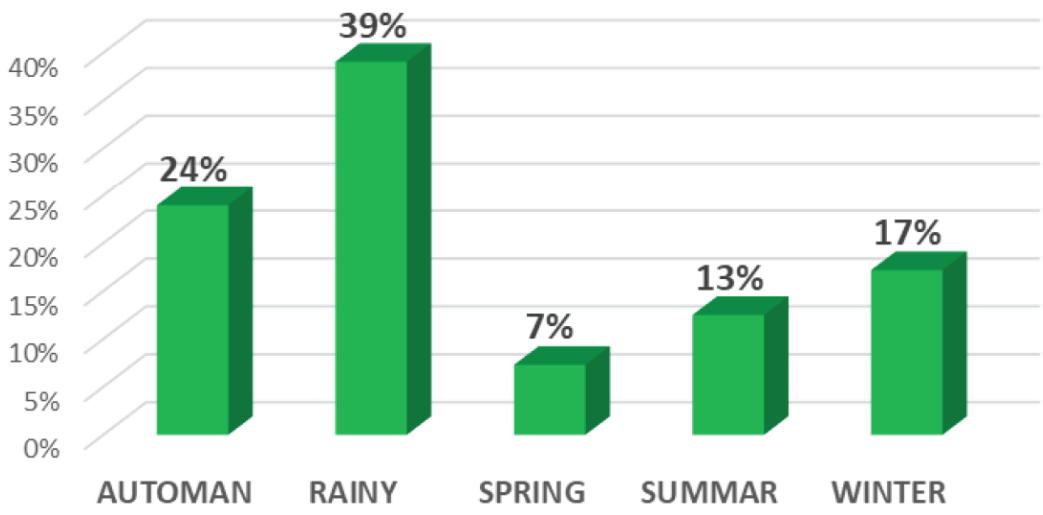




\section{ACKNOWLEDGEMENTS}

The authors are thankful to the Management team of BAIF Development Research Foundation and all stakeholders in the study area those who participated and cooperated during the study

\section{REFERENCES}

[1] Hassan F, Khan MS, Rehman MS, Sarwar M, Bhatti SA. Seasonality of calving in Nili-Ravi buffaloes, purebred Sahiwal and crossbred cattle in Pakistan. Ital J Anim Sci 2007; 6(Suppl. 2): 1298-1301. https://doi.org/10.4081/ijas.2007.s2.1298

[2] Hussain Z. Seasonal variation in breeding and calving pattern of Nili- Ravi buffaloes in Azad Kashmir, Pakistan. Buffalo Bull 2007; 26(4): 127-130.
[3] Anonymous, Annual Report (2007-08) of Network Project on Buffalo Improvement.

[4] Potdar VV, Khadse JR, Joshi SA, Gaundare YS, Swaminathan M, Phadke NL, Pande AB. Seasonal Variation of Calving in Murrah Buffalo in different Agro Climatic Zones of Uttar Pradesh, India. International Journal of Current Microbiology and Applied Sciences 2019; 8(5). https://doi.org/10.20546/ijcmas.2019.805.140

[5] Reddy AO, Ramesha KP, Rao MK. Effect of climate on the incidence of oestrus, conception and cycle length in Murrah buffaloes. Indian J Anim Sci 1999; 69(7): 485-489.

[6] Misra MS, Sengupta BP. Climatic environment and reproductive behaviour of buffaloes. III. Observations on semen quality of buffalo maintained under two different housing conditions. Indian J Dairy Sci 1965; 18: 130-133.

[7] El-Sheikh AS. The reproductive performance of the buffalo in Egypt. Indian J Dairy Sci 1987; 20: 8995.

(C) 2019 Potdar et al.; Licensee Lifescience Global.

This is an open access article licensed under the terms of the Creative Commons Attribution Non-Commercial License (http://creativecommons.org/licenses/by-nc/3.0/) which permits unrestricted, non-commercial use, distribution and reproduction in any medium, provided the work is properly cited. 